\title{
РОЛЬ ПЕРЕКЛАДУ \\ В НАВЧАННІ УКРАЇНСЬКОЇ МОВИ ЯК ІНОЗЕМНОЇ
}

\author{
ОКСАНА БАРАНІВСЬКА \\ Ягеллонський університет, Краків - Польща \\ ROLA PRZEKŁADU \\ W NAUCE JEZYKA UKRAIŃSKIEGO JAKO OBCEGO \\ OKSANA BARANIWSKA \\ Uniwersytet Jagielloński, Kraków — Polska
}

STRESZCZENIE. Artykuł został poświęcony roli przekładu w nauce języka ukraińskiego jako obcego. Przedstawiono rezultaty ankiet przeprowadzonych wśród studentów filologii ukraińskiej Uniwersytetu Jagiellońskiego i Państwowej Wyższej Szkoły Wschodnioeuropejskiej w Przemyślu (pytania: 1) w jaki sposób przekład pomaga w nauce języka oraz 2) tłumaczenie jakich tekstów jest najbardziej skuteczne dla nauki języka obcego).

\section{THE ROLE OF TRANSLATION IN TEACHING UKRAINIAN AS A FOREIGN LANGUAGE}

\author{
OXANA BARANIVSKA \\ Jagiellonian University, Krakow — Poland
}

\begin{abstract}
The article focuses on the analysis of the role of translation in the process of teaching Ukrainian as a foreign language. The results are based on intervewing students who study Ukrainian in Jagiellonian University, and Higher State East-European School in Pshemys'1. Certain questions have been analyzed: 1) how does translation help in mastering a language? 2) translation of what texts helps to get the best results?
\end{abstract}

$\mathrm{P}$

оль перекладу як однієї зі складових елементів процесу вивчення й навчання іноземної мови, без перебільшень, надзвичайно велика. Йдеться про його усну й писемну форми. Поряд із читанням, слуханням, мовленням, писанням, як відомо, перекладу теж належить вагоме місце в навчальному процесі. Проте сучасна методика навчання іноземнии мовам дещо „відсуває” переклад, ставлячи на перше місце комунікативний підхід. Та чи варто відмовлятися від перекладу? Не йдеться про те, що його роль повинна бути стрижневою, а про те, що його бажано використовувати поряд із іншими дидактичними методами.

Переклад у дидактиці, а також навчання перекладу здійснюється на основі актуалізації подібних, а навіть часто тих самих технік розвитку мовних умінь i навичок ${ }^{1}$. Проблема використання перекладу в процесі вивчення мови не $€$ новою: систематично з'являються нові дослідження й відбуваються нові дискуciï. Насамперед вони виникають у середовищі викладачів іноземних мов. Серед актуальних досліджень зазначеної проблеми можемо виділити праці А. Пшей-

\footnotetext{
${ }^{1}$ P. Płusa, Rozwijanie kompetencji przekładu i ksztatcenie tlumaczy, Katowice 2007.
} 
біша ${ }^{2}$, Ф. Гручі ${ }^{3}$, П. Плуси ${ }^{4}$. Перший серед названих авторів зазначає, що „переклад, який робить учень у процесі вивчення іноземної мови, $є$ передовсім засобом, за допомогою якого зреалізовуються певні дидактичні цілі, зокрема розуміння іноземної мови, опанування лексикою й розуміння граматичної будови, вміння висловити думку тощо”. Свої погляди він підсумовує так: „Переклад $\epsilon$ тільки одним із дидактичних засобів, що використовуються в сучасній методиці навчання іноземних мов" писав Ф. Груча, який зокрема не погоджується з вимогами сучасної методики, що відкидає переклад у тінь. На його думку, погляди методистів, які вважають переклад несуттєвим у процесі навчання іноземних мов, науково необгрунтовані ${ }^{7}$.

Здавалось би, що переклад можна пропонувати студенту тоді, коли в нього вже сформувалися певні знання, вміння й навички з іноземної мови. 3 одного боку, це, справді, так. Але з іншого, — треба враховувати, що ці вміння й навички формуються завдяки перекладу, адже переклад може бути процесом, що функціонує як на вербальному, так і на текстовому рівнях, він може впливати на розвиток окремих компетенцій студента. Відтак переклад тексту (як 3 мови А мовою Б, так і навпаки) віддзеркалюється в розвитку вміння його сприйняття, читання, а далі — графічного запису, натомість усний переклад — це розвиток уміння слухати, сприймати текст ${ }^{8}$.

Сьогодні майже в кожному навчальному закладі виокремлено систему предметів, що формують перекладознавчий блок як теоретичного, так і практичного характеру. Наприклад, на кафедрі україністики Ягеллонського університету студентам пропонують транслаторику (60 годин), художній переклад (60 годин), переклад спеціалізованих текстів (30 годин), критику перекладу (30 годин), основи перекладознавства (60 годин), перекладацьку майстерність (30 годин). Перший - на 3 курсі ліценціату, а всі інші — в магістратурі (два курси) зі спеціалізації „перекладознавство”. Виходить, що студенти можуть перекладати тільки 60 годин упродовж трьох років навчання і $210-$ протягом двох наступних. Загалом, у студента-україніста, який навчається 5 курсів, $\epsilon$ можливість перекладати 270 годин, причому 270 - це теорія 3 практикою, а не сам практичний курс перекладу, тобто насправді 200 годин. Багато це чи мало? 3 погляду навчальної програми вищої школи це нормально. Але чи ці години дадуть змогу удосконалити знання в галузі практичного перекладу? Та постає одразу й наступне питання: щоб перекладати (навіть вибрати перекладознавчу спеціалізацію), треба володіти мовою на певному рівні, адже ці 210 годин занять у магістратурі призначені для людей, які вже спроможні перекладати.

Тож чи роль перекладу зводиться тільки до прослуховування вище перерахованих предметів? Напевно, ні. Адже з самого початку вивчення мови маємо справу з найелементарнішим перекладом простих речень, іноді складних

${ }^{2}$ A. Przejbisz, Rola tlumaczenia w nauczaniu języków obcych, [w:] F. Grucza (red.): Polska myśl glottodydaktyczna. Warszawa 1979, s. 357-376.

${ }^{3}$ F. Grucza, Nauczanie języków obcych a tlumaczenie, [w:] F. Grucza (red.): Polska myśl glottodydaktyczna, Warszawa 1979, s. 314-326.

${ }^{4}$ P. Płu sa, Ibidem.

${ }^{5}$ A. Przejbisz, Ibidem, s. 359.

${ }^{6}$ A. Przejbisz, Ibidem, s. 362.

${ }^{7}$ F. Grucza, Ibidem., s. 326.

${ }^{8}$ P. Jóźwikiewicz, Przekład a proces nauczania języka ukraińskiego, Теорія і практика викладання украӥнської мови як іноземної, Львів 2007, вип. 2, s. 213. 
(з двома граматичними основами максимально). Вивчення ж мови не полягає у зазубрюванні „сухих” слів без контексту. Найпростіша річ (хоча це лише на перший погляд може видаватися найпростішим) - вивчити напам'ять слова (наприклад, двадцять нових слів) і пишатися тим, що сьогодні збагатився словниковий запас. Але чи знання тих двадцяти слів без контекстуального використання буде достатнім? Мабуть, ні. По-перше, якщо слово належить до самостійних частин мови, то його сполучуваність вимагатиме керування, узгодження чи прилягання, що найкраще (і найпростіше) демонструється в тексті. По-друге, в процесі перекладу бачимо обидві конструкції як мовою джерела, так і мовою перекладу.

Говорячи про переклад на заняттях з української мови як іноземної, маємо на увазі переклад як українською (в нашому випадку з польської), так і з української (польською). Переклад в один бік (наприклад, тільки українською) буде неповний. Звичайно, при цьому запам'ятається більше граматичних конструкцій і лексики, але вивчення лексики також буває ефективним у процесі перекладу текстів рідною мовою (з іноземної).

Багаторічна практика викладання української мови в Ягеллонському університеті і занять з практичного перекладу (переклад спеціалізованих текстів) у Вищій державній східноєвропейській школі в Перемишлі довела, що переклад текстів „в обидва боки” дає позитивні результати.

Комунікативний метод, що сьогодні посідає передові позиції, теж є важливим для вивчення мови, але для підготовки філологів-україністів цього підходу замало. Адже у філолога-україніста (чи русиста, богеміста) повинні бути розвинуті однаково всі компетенції: граматична, лексична, стилістична, орфографічна. Якщо навчання мови базуватиметься тільки на комунікативному аспекті, вміння грамотно писати й висловлювати свою думку може (хоча не завжди) трохи „кульгати". Комунікативний аспект, як видається, найбільш корисний на курсах іноземних мов. Але філолог повинен уміти більше, ніж пересічний носій мови.

Щоб з'ясувати, якою є роль перекладу у вивченні іноземної мови, було проведено опитування серед студентів-україністів Ягеллонського університету і Вищої державної східноєвропейської школи в Перемишлі. Запропоновано два запитання: 1. Наскільки переклад дає змогу опанувати мову? і 2. Переклад яких текстів допомагає найкраще і найшвидше вивчити мову? На перше питання маємо такі відповіді: ${ }^{9}$

- Завдяки перекладу можна вивчити багато слів, а також пригадати ті, що траплялися раніше. Переклад допомагає краще писати й швидше навчитися розмовляти українською;

- Переклад допомагає збагатити словниковий запас кожної мови, зрозуміти специфіку даної мови, розвиває нашу креативність;

- Вивчення напам'ять слів, написаних у стовпчик (словничок), не дає бажаного результату, оскільки їх швидко забувають. А от слова, вжиті в реченні, набагато легше засвоїти. У процесі перекладу виробляються навички щодо використання прийменників. Переклад дає змогу грамотно будувати синтаксичні структури;

- Переклад - це найважливіша частина наших занять (Це відповіды cmyдентки, яка мріє стати перекладачем - О. Б.);

- Завдяки перекладу вивчаємо різні конструкції, а також запам’ятовуємо написання слів;

\footnotetext{
${ }^{9}$ Кожна відповідь (окремого студента) починається з нового рядка.
} 
- Під час перекладу збагачується словниковий запас, завжди є можливість порівняти структуру мови, будову речень; у процесі перекладу автоматично спрацьовує візуальна пам' ять, а це знову ж таки поповнення словникового запасу;

- У процесі здійснення перекладу студент оволодіває лексичною базою мови, вчиться реалізувати певні синтаксичні структури (особливо прийменникового типу), підвищує свій граматичний рівень;

- Переклад дає змогу більше працювати зі словником, а також бачити різні варіанти перекладу одного й того самого речення (синонімічні конструкції);

- Переклад збагачує наші знання не тільки на рівні граматики чи орфографіï, але й на рівні спеціалізованої лексики (коли перекладаємо тексти з різних галузей знань).

Усі студенти (без винятку) вважають, що роль перекладу є вагомою. Без нього неможливе добре оволодіти іноземною мовою.

Відповіді на друге запитання теж не були надто різними чи протилежними. Більшість з опитуваних відповіла, що найкращими для вивчення мови є публіцистичні тексти (іхній переклад), зокрема почерпнуті з Інтернету. Ось що відповіли майбутні філологи-україністи:

- Під час вивчення мови найбільше допомагають тексти, пов'язані зі щоденним життям, торгівлею, а також медичні, юридичні;

- Найкращими для перекладу є науково-популярні тексти;

- Ц Цікавими є економічні, юридичні тексти, а також есе;

- Важливо, щоб тексти, які перекладаємо на заняттях, не були занадто важкі. Вони повинні стосуватися всіх сфер життя. Спеціалізовані тексти можна перекладати, але тільки час від часу;

- Слід перекладати різноманітні тексти - публіцистичні, наукові, художні, а також тексти, що містять елементи розмовного стилю, слова, якими послуговується українське суспільство щоденно. А завдяки цьому можна одразу перекладати “живе слово”;

- Найкращими для перекладу є тексти, що походять з Інтернет-мережі. Наукові тексти перекладати важко;

- Тексти, що цікавлять студентів і які студенти перекладатимуть із задоволенням, найчастіше належать до публіцистичного стилю. Ефективним для вивчення мови є також художній стиль, але він важчий, зважаючи на наявність великої кількості художніх засобів;

- Вивчати іноземну (українську) мову допомагають художні тексти (значна розмовна база, синонімічні ряди, множинність синтаксичних структур). Вони розвивають читацьку думку, мислення;

- Для вивчення мови варто перекладати тексти зі сфери політики. Найважчими для перекладу є тексти, що містять елементи гумору, а також історичні;

- Корисним і цікавим є переклад спеціалізованих текстів - юридичних, медичних, економічних;

- Найкраще допомагають засвоїти мову тексти, що стосуються різних сфер життя - здоров'я, науки, культури. Завдяки ним збагачуємо свій словниковий запас. Хоча переклад юридичних й економічних текстів набагато важчий, ніж тексти з вищезазначених галузей, проте їх теж слід перекладати, щоб краще вивчити мову. Переклад публіцистичних текстів частіше ставатиме в пригоді, аніж переклад художньої літератури.

Як показують відповіді студентів, усі вони вважають, що переклад - ефективна форма роботи (щоправда, іноді думки не збігаються, наприклад щодо того,чи у вивченні мови допомагає переклад художніх текстів). 
Зважаючи на очікування студентів, намагаємося йти їм назустріч. У своїй роботі найчастіше використовуємо публіцистичні тексти (передовсім 3 Інтернет-видань). Їхньою перевагою $є$ актуальність, періодичність, універсальність й автентичність, а також те, що вони невеликого обсягу, що теж суттєво в навчанні іноземної мови ${ }^{10}$. Публіцистичні тексти містять мовний матеріал, багатий на граматичні, стилістичні, лексичні (напр. синонімічні) форми. Тематично ці тексти теж різні.

Актуальність у дидактиці важлива з двох причин: 1) завжди свіжа інформація, а це зацікавлює студентів більше, аніж інформація кількарічної давності; 2) мовою (лексикою) публіцистики послуговується широке коло носіїв мови. Переклад публіцистичних текстів є відмінною вправою для закріплення практичних знань 3 мови, вправою, що дає змогу перевірити граматичну, стилістичну, орфографічну компетенцію студента, його лексичне багатство й культуру мовлення, а також уміння писати, тобто доносити до читача чи слухача текст. Перекладати варто й рідною мовою, й іноземною. Однак не слід зовсім відмовлятися від перекладу художніх текстів.

I художня література (різні жанри), й публіцистика (газети, журнали, Інтернет-видання тощо) щонайкраще ,пристосовані” до реалізації завдань навчання іноземної мови, адже:

- публіцистичний і художній тексти містять оригінальний, автентичний мовний матеріал, що є необхідним засобом навчання й вивчення мови;

- характеризуються тим, що містять актуальну інформацію про культуру й реалії країни;

- художні тексти багаті на жаргонізми, історизми, епітети, метафори, фразеологізми, зокрема й прислів'я і приказки і под., запам'ятовування яких можливе тільки завдяки роботі з текстом (спочатку під час читання, а пізніше під час перекладу);

ку, але й нові структури. Як відомо, нові слова добре запам'ятовуються саме в контексті, тому вивчення мови найкраще спроектувати на текст, зокрема й перекладаючи його.

Очевидно, вивчення мови не може базуватися тільки на перекладі текстів, тому що така методика може стати небезпечною. Адже цей процес багатовекторний і взаємопов'язаний: слухання тексту і його розуміння - запорука доброго перекладу (усного), вміння грамотно висловити свою думку в усному мовленні й на письмі (граматичні, стилістичні, лексичні й орфографічні норми) теж $є$ важливим у володінні мовою.

А відповіддю на роздуми про те, перекладати чи не перекладати на заняттях 3 мови (іноземної), нехай стануть слова Ф. Гручі: „Усі засоби, що є ефективними, повинні використовуватися в навчанні іноземним мовам"11.

\footnotetext{
${ }^{10}$ A. Kozłowski, Metodyka nauczania języków obcych $w$ szkolnictwie średnim $i$ wyższym, Piotrków Trybunalski 1996, s. 102.

${ }^{11}$ F. Grucza, Ibidem, s. 323.
} 